\title{
Magazyn Konsygnacyjny w Polsce
}

Streszczenie. W artykule przedstawiono warunki funkcjonowania magazynu konsygnacyjnego w Polsce, omówiono przepisy i problemy związane z jego funkcjonowaniem, opisano główne błędy popełnione przez ustawodawcę i wskazano proponowane zmiany legislacyjne, które ułatwią korzystanie z magazynu konsygnacyjnego większej grupie podatników.

Słowa kluczowe: magazyn konsygnacyjny, wewnątrzwspólnotowe nabycie towarów (WNT).

\section{WPROWADZENIE}

Celem niniejszego artykułu jest przedstawienie zasad funkcjonowania w Polsce magazynów konsygnacyjnych, które umożliwiają płatnikom VAT uproszczenie rozliczeń związanych $\mathrm{z}$ dokonywanymi transakcjami wewnątrzwspólnotowymi. Nowelizacja ustawy o podatku od towarów i usług z dnia 1.12.2008 r. wprowadziła uproszczenia dla transakcji prowadzonych za pośrednictwem magazynów konsygnacyjnych ${ }^{1}$. W artykule zostaną omówione zasady funkcjonowania magazynów konsygnacyjnych i dokonana będzie analiza przepisów obowiązujących w prawie europejskim oraz polskich przepisów dotyczących zasad funkcjonowania magazynów konsygnacyjnych na terytorium Polski, ujętych w ustawie o podatku od towarów i usług. Przedstawiona zostanie również propozycja zmian przepisów tej ustawy.

* Doradca podatkowy, doktorant Akademii Leona Koźmińskiego w Warszawie, e-mail: mategogol@gmail.com

${ }^{1}$ Art. 1 ust. 15 ustawy z dnia 7 listopada 2008 r. o zmianie ustawy o podatku od towarów i usług oraz niektórych innych ustaw (Dz.U. z 2008 r. Nr 209, poz. 1320). 
W dzisiejszym, globalizującym się świecie przedsiębiorstwa zmuszone są do efektywnego zarządzania swoimi zasobami, minimalizowania kosztów i powiększania zysków. Jedną z metod ograniczenia kosztów związanych $\mathrm{z}$ posiadaniem zasobów jest dostawa just in time (z ang. - 'dokładnie na czas'). Celem tej metody jest skrócenie czasu produkcji do minimum oraz redukcja zapasów i obniżenie kosztów ich utrzymania. W przypadku kooperacji z kontrahentami z różnych państw, często z innych kontynentów, producenci szukają alternatywnych rozwiązań, takim są np. składy konsygnacyjne. Zgodnie z założeniem koncepcji składów, na dostawcy ciąży obowiązek ich utrzymania. Producent odpowiedzialny jest jedynie za pobranie towarów z magazynu, a obowiązek ich rozliczenia występuje z chwilą ich użycia. Możemy wyróżnić dwa typy składów: call off stock (brak polskiej nazwy), gdzie odbiorca towarów jest $\mathrm{z}$ góry znany, oraz consignment stock (magazyn konsygnacyjny), w którym towar przeznaczony jest dla wielu nabywców.

\section{INSTYTUCJA MAGAZYNU KONSYGNACYJNEGO W PRAWIE EUROPEJSKIM}

Problematyka składów konsygnacyjnych została poruszona na gruncie prawa europejskiego. W międzynarodowych operacjach gospodarczych dochodzi coraz częściej do transakcji z wykorzystaniem składów konsygnacyjnych.

Dla podmiotów korzystających z tego rodzaju uproszczeń niezwykle istotne jest rozróżnienie na: consignment stock (składy konsygnacyjne), które tworzą swoisty rodzaj centrum dystrybucyjnego, gdzie towar przeznaczony jest dla wielu odbiorców, oraz call off stock (brak polskiego odpowiednika), w którym odbiorca towarów jest znany z góry. Cechą charakterystyczną obu tych rodzajów składów jest to, że podmiot dokonuje przemieszczenia towarów pomiędzy krajami, składuje je w magazynie i dokonuje sprzedaży w przypadku otrzymania zamówienia od odbiorcy ${ }^{2}$. Przed utworzeniem w Europie instytucji wspólnego rynku funkcję taką pełniły składy celne $e^{3}$. W ramach transakcji przy wykorzystaniu składów konsygnacyjnych odbywają się następujące operacje podlegające opodatkowaniu:

- przemieszczenie towarów z kraju Unii Europejskiej do magazynu konsygnacyjnego mieszczącego się w innym kraju Unii Europejskiej - rozumiane jako wewnątrzwspólnotowa dostawa towarów;

${ }^{2}$ P. Skorupa, Transakcje podlegajace opodatkowaniu, [w:] J. Martini (red.), Dyrektywa VAT 2006/112/WE, Warszawa 2010, s. 196.

${ }^{3}$ K. Sach, R. Namysłowski, Dyrektywa VAT. Komentarz, Warszawa 2008, s. 259. 
- przemieszczenie towarów z kraju Unii Europejskiej do magazynu konsygnacyjnego mieszczącego się w innym kraju Unii Europejskiej - rozumiane jako wewnątrzwspólnotowe nabycie towarów w kraju położenia magazynu;

- dostawy dla ostatecznego nabywcy towarów na terenie kraju położenia magazynu konsygnacyjnego.

W przypadku dokonywania transakcji za pomocą magazynów konsygnacyjnych, na podatniku państwa członkowskiego Unii Europejskiej ciąży obowiązek rejestracji dla celów podatku od wartości dodanej w państwie przeznaczenia towarów ${ }^{4}$. Po 1 stycznia 1993 r. doszło do rozbieżności w stosowaniu przepisów dotyczących transakcji z wykorzystaniem magazynów konsygnacyjnych. Rozwiązanie powyższe wymuszało w wielu państwach należących do Unii Europejskiej rejestrację dla celów podatku od wartości dodanej. Z kolei państwa takie jak Wielka Brytania, Węgry, Słowacja, Łotwa, Finlandia uznały, że na podmiocie zagranicznym będącym właścicielem towaru nie ciąży obowiązek rejestracji na potrzeby podatku od wartości dodanej w państwie, w którym znajduje się magazyn. Obowiązek rozliczenia transakcji będzie ciążył na podatniku będącym ostatecznym nabywcą towarów. Możliwość stosowania tego rodzaju uproszczenia została potwierdzona przez Komisję Europejską ${ }^{5}$. Instytucja magazynu konsygnacyjnego nie ma swoich podstaw prawnych w Dyrektywie 2006/112/WE (dalej: Dyrektywa VAT), jednak ww. uproszczenia są stosowane przez wiele państw członkowskich i akceptowane przez Komisję Europejską ${ }^{6}$. Dla stosowania tego rodzaju uproszczenia możemy wyróżnić wyżej już wspomniane dwa rodzaje magazynów konsygnacyjnych. Pierwszy z nich, consignment stock (skład konsygnacyjny) to magazyn, z którego towary mogą być dostarczane większej liczbie odbiorców ${ }^{7}$. Drugi rodzaj magazynu, tzw. call off stock (brak polskiego odpowiednika nazwy), odznacza się tym, że odbiorca towarów w nim składowanych jest z góry znany $^{8}$. Zastosowanie uproszczeń związanych ze składami konsygnacyjnymi jest zależne od tego, czy w danym państwie członkowskim funkcjonują przepisy odnoszące się do magazynów konsygnacyjnych. Na wprowadzenie

${ }^{4}$ P. Skorupa, Transakcje podlegające opodatkowaniu, [w:] J. Martini (red.), op. cit., s. 196.

${ }^{5}$ K. Sach, R. Namysłowski, op. cit., s. 259.

${ }^{6}$ T. Michalik, Komentarz 2012 do art. 2 ustawy o podatku od towarów i usług, System Informacji Prawnej Legalis.

${ }^{7}$ P. Skorupa, M. Wojda, Funkcjonowanie składów konsygnacyjnych oraz call-off stock w Polsce, „Przegląd Podatkowy” 2009, z. 5, s. 21.

${ }^{8}$ A. Bartosiewicz, R. Kubacki, Komentarz VAT, Warszawa 2010, s. 198. 
powyższych przepisów zdecydowały się: Austria, Belgia, Cypr, Czechy, Dania, Finlandia, Francja, Holandia, Irlandia, Litwa, Łotwa, Malta, Rumunia, Słowacja, Słowenia, Węgry, Wielka Brytania i Włochy.

W państwach, które nie wprowadziły przepisów dotyczących magazynów konsygnacyjnych, nie ma możliwości korzystania z uproszczeń podatkowych dla podmiotów prowadzących powyższe magazyny9 (tu przykładem są Niemcy $)^{10}$.

3. MAgAZYN KONSYGNACYJNY W ŚWIETLE POLSKICH PRZEPISÓW USTAWY O PODATKU OD TOWARÓW I USŁUG

Polski ustawodawca zdecydował się na rozwiązanie drugie, czyli magazyny typu call off stock, podobnie jak większość państw Unii Europejskiej ${ }^{11}$. Takie rozwiązanie ma pozytywne skutki ekonomiczne dla budżetu państwa. Dzięki wprowadzonym przepisom zwiększyła się atrakcyjność polskiej gospodarki ${ }^{12}$. Podmioty zagraniczne, decydując się na lokowanie centrów dystrybucyjnych, biorą pod uwagę możliwość korzystania $\mathrm{z}$ ułatwień podatkowych dla prowadzących magazyny konsygnacyjne ${ }^{13}$. W krajach naszego regionu ww. ułatwienia istnieją w Czechach, na Łotwie, Węgrzech, Słowacji, Litwie ${ }^{14}$.

Istota magazynu konsygnacyjnego w Polsce polega na tym, że:

- dostawca towarów pozostaje ich właścicielem do chwili pobrania z magazynu. Na nim spoczywają koszty składowania towarów (również inne ryzyka);

- towary są dostarczane do polskiego nabywcy przez zagranicznego dostawcę (lub odwrotnie);

- polski podatnik pobiera towary z magazynu w momencie, kiedy są mu potrzebne, i dopiero wtedy ponosi ryzyko związane $z$ tymi towarami (możliwa jest również sytuacja odwrotna) ${ }^{15}$.

${ }^{9}$ A. Bartosiewicz, D. Kosacka-Łędzewicz, Wewnątrzwspólnotowa dostawa towarów, Vademecum Doradcy Podatkowego.

${ }^{10}$ A. Ball, Consignment and Call of Stock Transaction between Poland and Germany, "International VAT Monitor" 2010, (September/October), s. 335.

${ }^{11}$ K. Lewandowski, P. Fałkowski, Dyrektywa VAT 2006/112. Komentarz do art. 20, System Informacji Prawnej Legalis.

${ }^{12} \mathrm{~K}$. Sachs, Ekspertyza w sprawie projektu ustawy o zmianie ustawy o podatku od towarów i usług (druk 734), Warszawa, 13 marca 2007, s. 2.

${ }^{13}$ R. Styczyński, Składy konsygnacyjne, Vademecum Doradcy Podatkowego, nr 103734.

${ }^{14}$ K. Sach, R. Namysłowski, op. cit., s. 260.

${ }^{15}$ R. Styczyński, op. cit. 
Główne ułatwienia przy dokonywaniu transakcji za pomocą magazynów konsygnacyjnych w Polsce to:

- przesunięcie obowiązku rozpoznania podatku z tytułu wewnątrzwspólnotowego nabycia towarów na polski podmiot prowadzący działalność gospodarczą. Rozwiązanie to umożliwia polskim organom podatkowym dokładniejszą kontrolę i daje możliwość wyeliminowania nadużyć w przypadku transakcji karuzelowych;

- eliminacja konieczności rejestracji dla celów VAT podatnika zagranicznego, odciążająca polskie organy podatkowe w zakresie jego kontroli, co w konsekwencji sprowadza się do niższych kosztów poboru podatku od wartości dodanej, przyczyniając się do tańszej administracji podatkowej.

Przed dokonaną nowelizacją wskazywano, iż ww. rozwiązanie może mieć negatywny wpływ na przepływy pieniężne dla budżetu państwa. Ze względu na wymienione wyżej zalety rozwiązanie to należy uznać za korzystne z punktu widzenia podatników i budżetu państwa ${ }^{16}$.

Istotą działania magazynu konsygnacyjnego jest odłożenie w czasie rozliczeń podatkowych $\mathrm{z}$ tytułu $\mathrm{WNT}^{17} \mathrm{i}$ brak możliwości rozliczenia podatku VAT przez dostawcę w sytuacji, gdy dokonuje on dostawy towarów do magazynu konsygnacyjnego. Obowiązek ten spoczywa na nabywcy towarów ${ }^{18}$.

3.1. Pojęcie magazynu konsygnacyjnego w polskiej ustawie o podatku od towarów i usług

Polski ustawodawca, w ramach przyjętej nowelizacji przepisów o podatku od towarów i usług, wprowadził do polskiego systemu podatkowego pojęcie magazynu konsygnacyjnego.

Pojęcie to zostało zawarte w art. 2 pkt 27c i 27d ustawy o podatku od towarów i usług. Skład konsygnacyjny określa się jako mieszaną konstrukcję prawną obejmującą swym zakresem zarówno umowę składu, jak i komisu.

Zgodnie z polskimi przepisami za magazyn konsygnacyjny należy uznać miejsce wyodrębnione, w którym przechowywane są towary podatnika VAT UE ${ }^{19}$. Towary są własnością podatnika podatku od wartości do-

${ }^{16}$ K. Sachs, op. cit, s. 3.

${ }^{17}$ R. Styczyński, op. cit.

${ }^{18}$ Pismo z dnia 29 kwietnia 2008 r., Izba Skarbowa w Warszawie IPPP1-443-326/08-4/AK, Lex Omega, nr 24320.

${ }^{19}$ A. Bartosiewicz, R. Kubacki, op. cit., s. 66-67. 
danej i zostały przez niego lub na jego rzecz przemieszczone $z$ terytorium państwa członkowskiego UE (innego niż Polska). Przeniesienie prawa do rozporządzania tymi towarami jak właściciel następuje w momencie ich pobrania ${ }^{20}$.

Zart. 2 pkt 27c ustawy o podatku od towarów i usług wynika, że przyjęto w Polsce koncepcję magazynu call off stock (pomimo że polski ustawodawca posługuje się pojęciem magazynu konsygnacyjnego, czyli consignment stock). Polski podatnik prowadzący magazyn otrzymuje i przechowuje towary tylko od jednego kontrahenta z Unii Europejskiej i tylko on (polski podatnik) może pobierać towary ze składu. Pojęcie składu konsygnacyjnego nie może odnosić się do uregulowań przyjętych w krajowych przepisach, gdyż oznaczałoby to prowadzenie składu konsygnacyjnego przez podmiot niezależny, w którym do składowania są uprawnione różne podmioty (dostawcy) i prawo do pobierania towarów posiadają różne podmioty ${ }^{21}$. Dlatego za magazyn konsygnacyjny należy uznać miejsce, w którym polski podatnik podatku od wartości dodanej, będący również zidentyfikowanym podatnikiem VAT UE, przechowuje towary należące do podatnika $\mathrm{z}$ innego państwa członkowskiego ${ }^{22}$. Błędne nazewnictwo dotyczące magazynów konsygnacyjnych w Polsce było podnoszone już na etapie prac sejmowych ${ }^{23}$.

\subsection{Miejsce przechowywania towarów}

W polskiej ustawie o podatku od towarów i usług nie zostały określone cechy, jakie powinno spełniać miejsce, w którym towary są przetrzymywane. Miejsce to nie może mieć charakteru wirtualnego. Ma to być wyodrębniony magazyn lub plac składowy ${ }^{24}$. Dodatkowo możliwa jest sytuacja, w której podatnik posiadający jeden budynek (halę) nie musi w sposób szczególny dostosowywać go na potrzeby prowadzenia magazynu konsygnacyjnego poprzez wyodrębnienie miejsca składowania dostarczonych towarów za pomocą ścian. Dopuszczalna jest sytuacja, w której podat-

\footnotetext{
${ }^{20}$ J. Zubrzycki, Leksykon VAT 2011, Wrocław 2011, s. 236.

${ }^{21}$ Ibidem, s. 68.

${ }^{22}$ Ibidem, s. 67.

${ }^{23} \mathrm{~K}$. Sach, Opinia o projekcie ustawy o zmianie ustawy o podatku od towarów i usług oraz o zmianie niektórych innych ustaw (druk nr 734), Warszawa, 4 sierpnia 2006 r., s. 2.

${ }^{24}$ J. Martini, P. Skorupa, M. Wojda, Komentarz 2009 do art. 2 ustawy o podatku od towarów i usług, System Informacji Prawnej Legalis.
} 
nik dokona wyodrębnienia powierzchni magazynu konsygnacyjnego poprzez wymalowanie linii oddzielających magazyn od innej powierzchni ${ }^{25}$. Wyodrębnienie takie może okazać się niewystarczające w sytuacji, gdy w jednym miejscu znajduje się kilka magazynów. Jak wskazuje P. Łabno, wyodrębnienie musi mieć charakter trwały oraz wyraźny ${ }^{26}$. By zachować trwały oraz wyraźny charakter wyodrębnienia, nie wystarczy namalowanie samej linii, lecz konieczne jest wskazanie właściciela magazynu konsygnacyjnego. Pogląd taki wspiera wykładnia językowa. Przez „wyraźny” należy rozumieć 'dający się łatwo i jednoznacznie zrozumieć' ${ }^{27}$. Samo wyodrębnienie magazynu za pomocą linii lub ścian jest niewystarczające, ponieważ nie umożliwia w sposób łatwy i precyzyjny określenia, do kogo należy magazyn. Ma to szczególne znaczenie w przypadku, gdy w jednym miejscu znajduje się kilka magazynów konsygnacyjnych. Dodatkowe oznaczenie, nie tylko za pomocą linii, lecz również nazwy, umożliwi łatwiejsze udowodnienie, że magazyn konsygnacyjny został wyodrębniony.

Nie ma też podstaw do uznania za niedopuszczalne na gruncie ustawy o podatku od towarów i usług sytuacji, w której w jednym pomieszczeniu będzie się mieścić kilka magazynów konsygnacyjnych, pod warunkiem, że każdy z nich będzie odpowiednio wyodrębniony i w każdym z nich będą przechowywane określone towary ${ }^{28}$. W sytuacji, gdy magazyn jest prowadzony przez podmiot trzeci (operatora logistycznego), nie ma możliwości skorzystania z uproszczenia, jakie daje prowadzenie magazynu konsygnacyjnego. Niedopuszczalna jest taka sytuacja, że dochodzi do przemieszczenia towarów do magazynu konsygnacyjnego, który jest prowadzony przez inny podmiot niż nabywca tych towarów ${ }^{29}$. Tylko w sytuacji, gdy magazyn prowadzony jest przez ostatecznego nabywcę towarów, uproszczenie ww. ma zastosowanie ${ }^{30}$.

${ }^{25}$ T. Michalik, Komentarz 2012 do art. 2 ustawy o podatku od towarów i usług, System Informacji Prawnej Legalis.

${ }^{26}$ P. Łabno, Definicja magazynu konsygnacyjnego, „Serwis Monitora Podatkowego” 2011, nr 4, s. 12.

${ }^{27}$ Słownik PWN (online), https://sjp.pwn.pl/szukaj/wyra\%C5\%BAny.html [dostęp 17.04.2019].

${ }^{28}$ T. Michalik, Komentarz 2016 do art. 2 ustawy o podatku od towarów i usług, System Informacji Prawnej Legalis.

${ }^{29}$ J. Martini, P. Skorupa, M. Wojda, Komentarz 2014 do art. 2 ustawy o podatku od towarów i ustug, System Informacji Prawnej Legalis.

${ }^{30}$ Pismo z dnia 29 czerwca 2010 r., Izba Skarbowa w Katowicach IBPP3/443-467/10/BWo, Lex Omega nr 36491. 
Polski podatnik prowadzący magazyn konsygnacyjny nie musi być właścicielem miejsca, w którym znajduje się ów magazyn. Może również dysponować lokalizacją (miejscem) na podstawie umowy najmu, dzierżawy itp. W przypadku posiadania dowolnego tytułu prawnego dotyczącego lokalizacji (miejsca) prowadzenia magazynu konsygnacyjnego zostaną spełnione przesłanki do jego prowadzenia ${ }^{31}$.

\subsection{Warunki dla prowadzącego magazyn konsygnacyjny}

Prowadzący magazyn konsygnacyjny musi spełnić szereg warunków określonych w art. 12a ustawy o podatku od towarów i usług w celu rozpoznania wewnątrzwspólnotowego nabycia towarów:

- dostawca towarów nie może być podatnikiem VAT w Polsce (czynnym lub zwolnionym);

- dostawca towarów musi być podatnikiem podatku od wartości dodanej poza Polską, nie może posiadać siedziby, stałego miejsca prowadzenia działalności lub stałego miejsca zamieszkania na terytorium Polski;

- nabywcą towarów musi być podmiot prowadzący magazyn konsygnacyjny, a z przepisów art. 2 pkt 27c ustawy o podatku od towarów i usług wynika, że musi być zarejestrowanym podatnikiem VAT UE;

- towary powinny zostać przemieszczone z innego państwa Unii Europejskiej i stanowić własność dostawcy;

- prowadzący magazyn konsygnacyjny zobowiązany jest do prowadzenia dokumentacji, sprawozdań związanych z ruchem towarów, jak i z prowadzeniem magazynu konsygnacyjnego ${ }^{32}$.

Bardzo podobne uregulowania dla podatników prowadzących magazyn konsygnacyjny zawiera czeska ustawa o podatku od wartości dodanej. Zgodnie z tymi przepisami:

- odbiorca końcowy musi być znany z góry;

- odbiorca końcowy musi być płatnikiem VAT w Czechach;

- dostawca nie może mieć siedziby, miejsca prowadzenia działalności gospodarczej lub placówki w Czechach i nie może być zarejestrowany (lub podlegać rejestracji) dla celów VAT w Czechach;

${ }^{31}$ J. Martini, P. Skorupa, M. Wojda, Komentarz 2010 do art. 2 ustawy o podatku od towarów i usług, System Informacji Prawnej Legalis.

${ }^{32}$ A. Bartosiewicz, R. Kubacki, op. cit., s. 200-202. 
- towary są dostarczane tylko do jednego podatnika podlegającego opodatkowaniu i to on rozlicza VAT z tytułu nabycia ${ }^{33}$.

Czy możliwe jest wykorzystanie ułatwień, jakie daje magazyn konsygnacyjny, w przypadku, gdy towary są dostarczane ze spółki matki do oddziału? Organy podatkowe w wydawanych przez siebie interpretacjach stoją na stanowisku, że oddział spółki zagranicznej nie jest oddzielnym podatnikiem VAT. Powyższy pogląd został potwierdzony przez Ministra Finansów w interpretacji ogólnej ${ }^{34}$. Nie można się zgodzić z tak kategorycznym stanowiskiem Ministra Finansów. W mojej ocenie oddział spółki zagranicznej może być oddzielnym podatnikiem VAT. Potwierdza to wyrok Trybunału Sprawiedliwości Unii Europejskiej. Oddział spółki może być samodzielnym podatnikiem VAT pod warunkiem ponoszenia ryzy$\mathrm{ka}^{35}$. Minister Finansów w interpretacji ogólnej pomija wyrok Trybunału Sprawiedliwości Unii Europejskiej, uznając, że oddział spółki zagranicznej nie jest samodzielnym podatnikiem $\mathrm{VAT}^{36}$. Do polskiego organu podatkowego należy ustalenie, czy oddział spółki zagranicznej ponosi ryzyko. W sytuacji, gdy oddział będzie ponosił ryzyko, nie ma przeszkód, by był oddzielnym podatnikiem VAT zarejestrowanym w Polsce i skorzystał z uregulowań dotyczących magazynów konsygnacyjnych. Nie jest natomiast możliwa sytuacja, w której oddział nieponoszący ryzyka będzie oddzielnym podatnikiem VAT. W takiej sytuacji oddział, który nie ponosi ryzyka, nie korzysta $z$ ułatwienia, jakie daje magazyn konsygnacyjny, ponieważ nie spełnia przesłanki, zgodnie z którą dostawca towarów nie może być podatnikiem podatku VAT w Polsce (czynnym lub zwolnionym). Oddział będzie niejako wyodrębnionym podmiotem ze struktury spółki matki i nie jest oddzielnym podatnikiem VAT, ponieważ nie ponosi ryzyka. $\mathrm{W}$ mojej ocenie mamy wtedy do czynienia $\mathrm{z}$ tym samym podatnikiem, który jedynie rejestruje się do VAT w Polsce. Podmiotem prowadzącym działalność w Polsce pozostaje przedsiębiorca zagraniczny (spółka matka),

${ }^{33}$ C. Platteeuw, P. Pestana Da Silva, Quick Reference to European VAT Compliance, http://books.google.pl/books?id=kZHnXzxzUzsC\&num=11\&hl=pl\&redir_esc=y [dostęp 5.04.2013].

${ }^{34}$ Wyjaśnienie Ministra Finansów z dnia 28 marca 2007 r., PT5-033-4/2006/IN/665, System Informacji Prawnej Legalis.

${ }^{35}$ Wyrok Europejskiego Trybunału Sprawiedliwości z 23 marca 2006 r. w sprawie Ministero dell'Economia e delle Finanze oraz Agenzia delle Entrate przeciwko FCE Bank, plc.C-210/04, System Informacji Prawnej Legalis.

${ }^{36}$ Wyjaśnienie Ministra Finansów z dnia 28 marca 2007 r., PT5-033-4/2006/IN/665, System Informacji Prawnej Legalis. 
a nie oddział, i nie może skorzystać z ułatwienia, jakie daje instytucja magazynu konsygnacyjnego.

Zagadnieniem wymagającym omówienia jest obowiązek rejestracji jako podatnika VAT UE dla prowadzącego magazyn konsygnacyjny. Powyższe należy rozstrzygnąć na gruncie przepisów krajowych i wspólnotowych. W przypadku magazynu konsygnacyjnego przepisy dyrektywy VAT nie regulują tej kwestii ${ }^{37}$. Zgodnie $z$ art. 2 pkt 27 c prowadzący magazyn konsygnacyjny musi być zarejestrowanym podatnikiem VAT UE.

Powyższe stanowisko wspiera wykładnia systemowa wewnętrzna. Na prowadzącym magazyn konsygnacyjny ciąży obowiązek zawiadomienia Naczelnika Urzędu Skarbowego o zamiarze prowadzenia magazynu konsygnacyjnego ${ }^{38}$. Przy dokonywaniu analizy tego przepisu nasuwa się wniosek, że Naczelnik Urzędu Skarbowego musi otrzymać zawiadomienie od podmiotu prowadzącego magazyn konsygnacyjny, a podmiotem prowadzącym magazyn konsygnacyjny musi być podmiot zarejestrowany jako podatnik VAT UE.

3.4. Ograniczenia w zakresie towarów, które mogą być przedmiotem obrotu przy wykorzystaniu magazynu konsygnacyjnego

Przepis art. 12a ustawy o podatku od towarów i usług nie zawiera wykazów towarów, które nie mogą być przedmiotem nabycia wewnątrzwspólnotowego przy wykorzystaniu magazynu konsygnacyjnego. Należy podkreślić, że niektóre towary będą podlegać określonym wymogom wynikającym $\mathrm{z}$ innych ustaw. Istotnym ograniczeniem nałożonym na nabywcę jest wykorzystanie tych towarów w działalności produkcyjnej lub usługowej prowadzonej przez nabywcę ${ }^{39}$. Zdaniem organu podatkowego, nie można mówić o działalności usługowej ani o działalności produkcyjnej w sytuacji, gdy podatnik dokonuje np. kompletacji sprzętu komputerowego w postaci gotowych zestawów ${ }^{40}$.

${ }^{37}$ T. Michalik, Komentarz 2018 do art. 2 ustawy o podatku od towarów i usług, System Informacji Prawnej Legalis.

${ }^{38}$ Art. 12a ust. 1 pkt 3 ustawy z dnia 11 marca 2004 r. o podatku od towarów i usług (Dz.U. z 2004 r. Nr 54, poz. 535).

${ }^{39}$ A. Bartosiewicz, R. Kubacki, op. cit., s. 200.

${ }^{40}$ Pismo z dnia 15 lipca 2011 r., Izba Skarbowa w Łodzi IPTPP2/443-10/11-4/BM, Lex Omega, nr 62704. 
Podatnik, który chce prowadzić magazyn konsygnacyjny, powinien powiadomić Naczelnika Urzędu Skarbowego o zamiarze prowadzenia takiej działalności. Zawiadomienie należy złożyć w stosownym terminie, tj. przed pierwszym wprowadzeniem przez podatnika VAT towaru do magazynu. Należy to uczynić na piśmie.

Zawiadomienie powinno zawierać:

- dane podatnika podatku od wartości dodanej dokonującego przemieszczenia towarów do magazynu konsygnacyjnego oraz prowadzącego magazyn konsygnacyjny, dotyczące ich nazw lub imion i nazwisk, numerów identyfikacyjnych stosowanych na potrzeby odpowiednio podatku od wartości dodanej i innych podatków, adresu siedziby działalności gospodarczej lub stałego miejsca prowadzenia działalności gospodarczej oraz adresu, pod którym znajduje się magazyn konsygnacyjny;

- oświadczenie podatnika podatku od wartości dodanej o tym, że zamierza dokonywać przemieszczenia towarów, o którym mowa w art. 11 ust. 1 ustawy o podatku od towarów i usług, do magazynu konsygnacyjnego; w oświadczeniu wskazuje się prowadzącego magazyn konsygnacyjny ${ }^{41}$.

Art. 12a ust. 2 ustawy o podatku od towarów i usług wprowadza ciekawe rozwiązanie odnośnie do zawiadomienia. Jeżeli zawiadomienie nie spełnia wymogów określonych w ust. 1 pkt 3 ww. ustawy, Naczelnik Urzędu Skarbowego w terminie 7 dni od otrzymania zawiadomienia wzywa do jego uzupełnienia. Przy analizie treści art. 12a ust. 2 ustawy nasuwa się pytanie, czy podatnik może prowadzić skład konsygnacyjny w sytuacji, gdy nie spełni wymogów z art. 12a ust. 1, a Naczelnik Urzędu Skarbowego nie wezwie podatnika w terminie 7 dni do uzupełnienia braków? W analizowanym przypadku podatnik nie będzie mógł korzystać z procedury uproszczonej. Tylko złożenie zawiadomienia zawierającego wszystkie elementy, o których mowa w art. 12 ust. 1 pkt 3, jest warunkiem zastosowania uproszczenia ${ }^{42}$. Należy wskazać, że przepisy ustawy o podatku od towarów i usług nie precyzują właściwości miejscowej. W wyniku nowelizacji ustawy o podatku od towarów i usług doszło do usunięcia przepisów odnośnie do właściwości miejscowej organów podatkowych w podatku od towarów i usług. Z dniem 1.01.2016 r. ustawodawca uchylił znaczną część przepisów

${ }^{41}$ J. Zubrzycki, op. cit., s. 238-239.

${ }^{42}$ T. Michalik, Komentarz 2012 do art. 12 a ustawy o podatku od towarów $i$ usług, System Informacji Prawnej Legalis. 
art. $3^{43}$. Aby ustalić właściwość miejscową, należy sięgnąć do przepisów Ordynacji podatkowej. Zgodnie z art. 17 Ordynacji podatkowej, miejscem właściwym do złożenia zawiadomienia będzie miejsce zamieszkania lub miejsce siedziby podatnika.

Ustawodawca określił też sposób postępowania w przypadku zmiany danych znajdujących się w zawiadomieniu. Na prowadzącym magazyn konsygnacyjny ciąży obowiązek zgłoszenia tych zmian w terminie 30 dni od momentu ich zaistnienia. W okresie pomiędzy dniem powstania zmiany a dniem upływu terminu zgłoszenia strony mogą korzystać z magazynu konsygnacyjnego w celu dokonywania transakcji wewnątrzwspólnotowych. W przypadku niedokonania zgłoszenia zmian w terminie $30 \mathrm{dni}$ w formie pisemnej Naczelnik Urzędu Skarbowego w zależności od charakteru zmian objętych zgłoszeniem może wstrzymywać lub nie transakcje wewnątrzwspólnotowe $\mathrm{z}$ wykorzystaniem magazynu konsygnacyjnego.

W przypadku, gdy zamiana dotyczy adresu magazynu konsygnacyjnego, nie ma możliwości dokonywania transakcji wewnątrzwspólnotowych. Natomiast zmiana adresu dostawcy nie skutkuje zakazem dokonywania takich transakcji ${ }^{44}$.

3.6. Obowiązek prowadzenia ewidencji przez prowadzącego magazyn konsygnacyjny

Na podmiocie prowadzącym magazyn konsygnacyjny ciąży obowiązek ewidencjonowania towarów sprowadzonych do magazynu. Ewidencja musi zawierać następujące elementy:

- datę wprowadzenia towarów do magazynu;

- datę pobrania towarów z magazynu;

- dane pozwalające na identyfikację towarów;

- w przypadku, o którym mowa w art. 20b ust. 3 ustawy o podatku od towarów i usług (w przypadku powrotnego ich przemieszczenia w terminie 24 miesięcy od dnia wprowadzenia towarów do magazynu) - także dane dotyczące powrotnego przemieszczenia towarów ${ }^{45}$.

${ }^{43}$ Art. 10 ustawy z dnia 10 września 2015 r. o zmianie ustawy - Ordynacja podatkowa oraz niektórych innych ustaw (Dz.U. 2015, poz. 1649).

${ }^{44}$ A. Bartosiewicz, R. Kubacki, op. cit., s. 202-203.

${ }^{45}$ T. Michalik, Komentarz 2016 do art. 20a ustawy o podatku od towarów i usług, System Informacji Prawnej Legalis. 
3.7. Moment powstania szczególnego obowiązku podatkowego

W art. 12a ust. 4-6 ustawodawca określił szczególny moment powstania obowiązku podatkowego przy wykorzystaniu magazynu konsygnacyjnego w następujących przypadkach:

- stwierdzenia braków towarów lub całkowitego ich zniszczenia;

- wykorzystania lub użycia towarów przechowywanych w magazynie;

- sytuacji, gdy towary nie zostały pobrane przez okres 24 miesięcy od dnia ich wprowadzenia do magazynu ${ }^{46}$.

Należy zwrócić uwagę na fakt, że towary znajdujące się w magazynie konsygnacyjnym mogą być tam przetrzymywane przez okres 24 miesięcy. W sytuacji, gdy nie zostaną pobrane w tym okresie, przyjmuje się fikcję prawną, że pobranie miało miejsce następnego dnia po upływie ww. okresu. Na prowadzącym magazyn konsygnacyjny ciąży obowiązek podatkowy z tytułu wewnątrzwspólnotowego nabycia towarów. Art. 20b ust. 3 wprowadza jednak istotne odstępstwo od tej zasady. Jeżeli towar nie został pobrany z magazynu, ale nastąpił powrotny wywóz tego towaru przed upływem 24 miesięcy do innego państwa członkowskiego, to takie działanie nie spowoduje powstania obowiązku podatkowego. Niestety, ustawodawca nie sprecyzował pojęcia powrotnego przemieszczenia towarów. Dlatego w tym zakresie należy dać prymat wykładni językowej i zwrot „z powrotem” powinno się rozumieć jako „w kierunku powrotnym”47. W analizowanym przepisie ustawodawcy chodziło raczej o zwrot towaru zagranicznemu dostawcy. Gdyby chodziło o przemieszczenie towaru do dowolnego państwa członkowskiego UE, ustawodawca nie zawarłby sformułowania „powrotne przemieszczenie”. Dokonując wykładni językowej, nie można przeprowadzić interpretacji przepisu w taki sposób, aby pominąć część przepisu ${ }^{48}$. W mojej ocenie, o powrotnym przemieszczeniu towarów możemy mówić w sytuacji przemieszczenia towarów do kraju, z którego towary zostały wysłane do magazynu konsygnacyjnego.

${ }^{46}$ Art. 12a, ust. 4-6 ustawy z dnia 11 marca 2004 r. o podatku od towarów i usług (Dz. U. z 2004 r. Nr 54, poz. 535).

${ }^{47}$ Słownik PWN (online), https://sjp.pwn.pl/szukaj/\%E2\%80\%9Ez\%20powrotem\% E2\%80\%9D\%20.html [dostęp 17.04.2019].

${ }^{48}$ B. Brzeziński, Podstawy wykładni prawa podatkowego, Ośrodek Doradztwa i Doskonalenia Kadr Sp. z o.o., Gdańsk 2008, s. 43. 
W takim przypadku transakcję uważa się za niebyłą i na podatniku nie ciąży obowiązek podatkowy z tytułu tych przemieszczeń ${ }^{49}$. Istotą magazynu typu call off stock jest to, aby towary nie były przetrzymywane przez czas nieokreślony, lecz tylko przez pewien okres i pobierane przez nabywcę w miarę potrzeb ${ }^{50}$. Warto zaznaczyć brak harmonizacji przepisów dotyczących call off stock. Toteż państwa członkowskie UE mogą regulować długość terminu, w którym towary powinny zostać pobrane $\mathrm{z}$ call off stock ${ }^{51}$. Polska wprowadziła dość długi termin w porównaniu na przykład do rozwiązań francuskich, zgodnie z którymi towary mogą przebywać w magazynie jedynie przez okres 3 miesięcy ${ }^{52}$. Są też państwa Unii Europejskiej, które wprowadziły nieograniczony czas przechowywania towarów w call off stock, są nimi np.: Holandia, Czechy, Węgry i Słowacja.

Odnosząc się do obowiązujących w Polsce przepisów dotyczących okresu, w którym towary muszą być pobrane z magazynu, należy podkreślić, że okres ten jest stosunkowo długi. Zważywszy na brak harmonizacji w kwestii terminu odnośnie do powrotnego przemieszczenia towarów i stanowisko doktryny, że istotą magazynu call off stock jest to, aby towary nie były przetrzymywane przez nieokreślony czas, lecz tylko przez pewien okres i pobierane przez nabywcę w miarę potrzeb ${ }^{53}$, należy uznać, że polski ustawodawca postąpił prawidłowo, określając maksymalnie czas, w jakim towary mogą pozostawać w magazynie.

W razie stwierdzenia braku towarów lub całkowitego ich zniszczenia przyjmuje się fikcyjnie, że towary zostały pobrane z magazynu. Za dzień pobrania towaru z magazynu uważa się dzień, w którym stwierdzono braki lub zniszczenie towarów znajdujących się w magazynie. W przypadku, gdy nie da się ustalić tego dnia, należy przyjąć, że towary zostały pobrane w dniu, w którym stwierdzono ich zniszczenie lub braki ${ }^{54}$, i na podatniku będzie ciążył obowiązek podatkowy z tytułu wewnątrzwspólnotowego nabycia towarów ${ }^{55}$.

\footnotetext{
${ }^{49}$ A. Bartosiewicz, R. Kubacki, op. cit., s. 345.

${ }^{50}$ Ibidem, s. 203.

${ }^{51}$ P. Skorupa, M. Wojda, op. cit.

${ }^{52}$ C. Platteeuw, P. Pestana Da Silva, op. cit.

${ }^{53}$ Ibidem, s. 203.
}

${ }^{54}$ D. Kosacka-Łędzewicz, B. Olszewski, Transakcje wewnątrzwspólnotowe, eksport, import - 2009, Wrocław 2009, s. 293.

${ }_{55}$ A. Bartosiewicz, R. Kubacki, op. cit., s. 203. 
Podatnik zobowiązany jest wystawić fakturę wewnętrzną z odpowiednią stawką podatkową. Faktura powinna zawierać naliczoną stawkę należnego podatku. Podatek ten będzie jednocześnie stanowił podatek naliczony możliwy do odliczenia na zasadach ogólnych ${ }^{56}$.

$\mathrm{W}$ przypadku, gdy towary przechowywane w magazynie konsygnacyjnym zostały użyte lub wykorzystane przed ich pobraniem z magazynu konsygnacyjnego, należy uznać, że pobranie tych towarów ma miejsce w dniu użycia lub wykorzystania tych towarów (zgodnie z art. 12a ust. 5) ${ }^{57}$.

Trzeba przy tym zauważyć, że gdy którykolwiek z warunków zawartych w art. 12a ust. 1 przestaje być spełniony, wówczas na podatniku, który przemieścił towar do magazynu konsygnacyjnego, będzie ciążył obowiązek podatkowy $z$ tytułu wewnątrzwspólnotowego nabycia towarów w stosunku do towarów pozostających w tym magazynie (zgodnie z art. 11 ust. 1) ${ }^{58}$. W przypadku pobrania towaru $\mathrm{z}$ magazynu na podatniku ciąży obowiązek wykazania wewnątrzwspólnotowego nabycia towarów ${ }^{59}$.

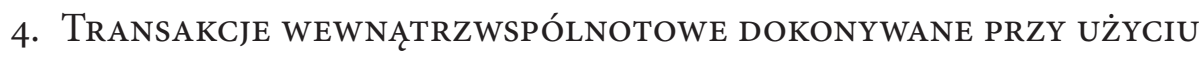
MAGAZYNU KONSYGNACYJNEGO NA GRUNCIE POLSKICH PRZEPISÓW USTAWY O PODATKU OD TOWARÓW I USŁUG

\subsection{Magazyn Konsygnacyjny a WNT}

Dostawa towarów do magazynu konsygnacyjnego nie powoduje powstania transakcji wewnątrzwspólnotowych. Obowiązek taki powstaje z chwilą pobrania towarów ze składu konsygnacyjnego, nie później jednak niż z dniem wystawienia faktury ${ }^{60}$.

W polskiej ustawie o podatku od towarów i usług uproszczenia związane z wykorzystaniem magazynów konsygnacyjnych zostały unormowane w art. 12a i 20b tej ustawy. W art. 12a ust. 1 ustawy o podatku od towarów i usług wskazane zostały warunki, których spełnienie skutkuje uznaniem przemieszczenia towarów przez podatnika podatku od wartości dodanej do

${ }^{56}$ T. Krywan, Czy należy opodatkować brakujące towary $w$ magazynie, „Biuletyn VAT" 2010, z. 2, s. 38.

${ }^{57}$ D. Kosacka-Łędzewicz, B. Olszewski, op. cit., s. 294.

${ }^{58}$ J. Zubrzycki, op. cit., s. 241.

${ }^{59}$ D. Kosacka-Łędzewicz, B. Olszewski, op. cit., s. 298.

${ }^{60}$ K. Musiał (red. nauk.), A. Bartosiewicz, Założenie magazynu konsygnacyjnego $w$ Polsce, Vademecum Doradcy Podatkowego. 
magazynu konsygnacyjnego $\mathrm{w}$ celu ich dostawy prowadzącemu magazyn konsygnacyjny oraz późniejszego uznania dostawy towarów za WNT u prowadzącego magazyn. Stosownie do wskazanej regulacji skorzystanie z uproszczenia związanego z magazynem konsygnacyjnym będzie możliwe, gdy:

1) dostawca podatnik podatku od wartości dodanej nie będzie zarejestrowany w Polsce jako podatnik VAT czynny lub zwolniony;

2) towary przechowywane w magazynie konsygnacyjnym przeznaczone będą do działalności produkcyjnej lub usługowej, z wyłączeniem działalności handlowej, przez prowadzącego magazyn konsygnacyjny;

3) prowadzący magazyn konsygnacyjny, przed pierwszym wprowadzeniem towarów do magazynu, zawiadomi w formie pisemnej właściwego Naczelnika Urzędu Skarbowego o zamiarze prowadzenia magazynu konsygnacyjnego;

4) prowadzący magazyn konsygnacyjny będzie prowadził ewidencję towarów:

- wprowadzanych do magazynu - zawierającą datę ich wprowadzenia i pobrania z magazynu oraz dane pozwalające na ich identyfikację,

- powrotnie przemieszczonych przez podatnika podatku od wartości dodanej - gdy w okresie 24 miesięcy od dnia wprowadzenia towarów do magazynu konsygnacyjnego nie zostały one pobrane i w związku z tym zostały powrotnie przemieszczone (w takiej sytuacji nie dochodzi do powstania obowiązku podatkowego w WNT) ${ }^{61}$.

Aby transakcja mogła zostać rozliczona przez nabywcę prowadzącego magazyn konsygnacyjny, powyższe warunki muszą zostać spełnione łącznie. W sytuacji, gdy nie są spełnione warunki z art. 12a ust. 1, powstaje obowiązek rozliczenia podatku $\mathrm{z}$ tytułu wewnątrzwspólnotowego nabycia towarów w stosunku to towarów, które znajdują się w magazynie konsygnacyjnym. Obowiązek ten będzie ciążył na podatniku od wartości dodanej, który dokonał dostawy tych towarów.

Przyjęte regulacje pociągają za sobą następujące skutki:

- wyłączają konieczność rejestracji na potrzeby podatku od wartości dodanej na terytorium Polski przez podmioty zagraniczne, które dokonują przemieszczenia towarów do magazynu konsygnacyjnego znajdującego się na terytorium Polski;

${ }^{61}$ Ł. Tuszyński, K. Szymaniak, Rozliczenia transakcji wewnątrzwspólnotowych przy wykorzystaniu magazynu konsygnacyjnego - problemy praktyczne, „Monitor Podatkowy” 2016, nr 6, s. 15. 
- powodują przesunięcie momentu powstania obowiązku podatkowego z tytułu wewnątrzwspólnotowego nabycia towarów do chwili pobrania towarów z magazynu;

- przenoszą obowiązek rozliczenia transakcji na polskiego podatnika prowadzącego magazyn konsygnacyjny.

Art. 12a ust. 1-3 wprowadza szczegółowe warunki, jakie należy spełnić, by uznać transakcję wewnątrzwspólnotową u polskiego podatnika podatku od wartości dodanej, a nie u podatnika VAT, który dokonuje przemieszczenia tych towarów. Z wyżej wymienionych przepisów wynika, że podatnik VAT, który przemieszcza towary do magazynu, nie może być zarejestrowany w Polsce jako podatnik podatku od wartości dodanej czynny lub zwolniony. Dodatkowo, prowadzący magazyn musi spełnić warunki formalne zawarte w przepisach. Podatnik, który prowadzi magazyn konsygnacyjny i pobiera $z$ niego przechowywane towary, może je przeznaczyć wyłącznie do działalności produkcyjnej lub usługowej, lecz nie handlowej ${ }^{62}$. Będzie on również zobowiązany do prowadzenie ewidencji.

\subsection{Magazyn Konsygnacyjny a WDT}

W przypadku, gdy dojdzie do dostawy towaru do miejsca odpowiadającego magazynowi konsygnacyjnemu w innym kraju UE niż Polska, obowiązek podatkowy powstaje $\mathrm{z}$ chwilą dostawy towarów ( $w$ momencie pobrania towaru przez nabywcę z magazynu konsygnacyjnego), nie później niż z chwilą wystawienia faktury potwierdzającej tę dostawę. Warunkiem powstania obowiązku podatkowego na powyższych zasadach jest, aby podatnik podatku od wartości dodanej zobowiązany był do wykazania dokonanego przemieszczenia towarów oraz dostawy towarów w innym niż Polska państwie członkowskim, jako WNT, w miesiącu, w którym u polskiego podatnika powstał obowiązek podatkowy z tytułu WDT.

Celowo należy w tym przypadku posłużyć się zwrotem „do miejsca odpowiadającego magazynowi konsygnacyjnemu w innym kraju”. Organy podatkowe stoją na stanowisku, że w przypadku dostawy towarów do magazynu konsygnacyjnego położonego w innym państwie członkowskim towary muszą być dostarczone do magazynu typu call of stock ${ }^{63}$. Powyższy pogląd akcepto-

${ }^{62}$ J. Zubrzycki, op. cit., s. 237-238.

${ }^{63}$ Pismo Dyrektora Izby Skarbowej w Warszawie z dnia 13 października 2014 r., IPPP3/443-698/14-2/KT, Lex Omega nr 255816. 
wany jest przez doktrynę $e^{64}$. Użycie w art. 20a ust. 1 zwrotu „odpowiadającego magazynowi konsygnacyjnemu” w znaczący sposób ogranicza możliwość skorzystania $\mathrm{z}$ ułatwienia, jakie daje magazyn konsygnacyjny $\mathrm{w}$ wewnątrzwspólnotowej dostawie towarów. Powyższa regulacja nie ma uzasadnienia, ponieważ nakłada na podatnika obowiązek weryfikacji, czy magazyn położony w innym państwie Wspólnoty spełnia cechy magazynu konsygnacyjnego położonego w Polsce. Nakłada to na dostawcę towarów do zagranicznego magazynu konsygnacyjnego obowiązek weryfikacji, czy dany magazyn jest magazynem konsygnacyjnym w rozumieniu polskiej ustawy o podatku od towarów i usług. Należałoby zastąpić zwrot „odpowiadającego magazynowi konsygnacyjnemu” zwrotem „do magazynu konsygnacyjnego w rozumieniu przepisów państwa, w którym transport się zakończył”. Takie rozwiązanie sprawi, że z ułatwienia, jakie daje magazyn konsygnacyjny, będzie można skorzystać w przypadku wysyłki towarów do większej liczby państw.

Należy wskazać, że w przypadku nieuznania przez organ podatkowy dostawy towarów do magazynu konsygnacyjnego (call off stock), transakcja będzie rozliczana jako przemieszczenie towarów i następująca po nim dostawa towarów. Dla polskiego podatnika istotne będzie to, czy może on zastosować stawkę 0\%. Organy podatkowe stoją na stanowisku, że polski podatnik dokonający dostawy do miejsca nieodpowiadającego magazynowi konsygnacyjnemu (call off stock) powinien zarejestrować się do VAT w państwie położenia magazynu, aby skorzystać ze stawki $0 \%{ }^{65}$. W rezultacie brak rejestracji w kraju położenia magazynu konsygnacyjnego (call off stock) skutkuje obowiązkiem opodatkowania i przesunięcia towarów do innego kraju UE według stawki właściwej dla dostaw krajowych ${ }^{66}$.

\section{Podstawa opodatkowania}

Co do zasady, w przypadku wewnątrzwspólnotowego nabycia towarów, w tym również:

- stwierdzenia braków towarów lub całkowitego ich zniszczenia,

- wykorzystania lub użycia towarów w magazynie,

${ }^{64}$ T. Michalik, Komentarz 2016 do art. 20a ustawy o podatku od towarów i ustug, System Informacji Prawnej Legalis.

${ }^{65}$ Pismo Dyrektor Izby Skarbowej w Katowicach z dnia 14.01.2015, IBPP4/443-495/14/PK, Lex Omega nr 252630.

${ }^{66}$ Ł. Tuszyński, K. Szymaniak, op. cit., s. 18. 
- niepobrania towarów przez okres 24 miesięcy od dnia ich wprowadzenia do magazynu,

zastosowanie będzie miał art. 29a ust. 1 ustawy o podatku od towarów i usług.

Zgodnie z ww. artykułem, podstawą do opodatkowania jest wszystko, co stanowi zapłatę, którą dokonujący dostawy towarów lub usługodawca otrzymał lub ma otrzymać z tytułu sprzedaży od nabywcy, usługobiorcy lub osoby trzeciej, łącznie z otrzymanymi dotacjami, subwencjami i innymi dopłatami o podobnym charakterze, mającymi bezpośredni wpływ na cenę towarów dostarczanych lub usług świadczonych przez podatnika ${ }^{67}$.

\section{PRZEPISY PRZEJŚCIOWE}

Podkreślić należy, że polskie podmioty, które przed wejściem w życie uproszczeń (1 grudnia 2008 r.) prowadziły składy konsygnacyjne, mogą prowadzić je dalej, jeśli spełniają warunki określone w art. 12a ust. 1 ustawy o podatku od towarów i usług ${ }^{68}$. Z analizy tego artykułu wynika, że nie jest możliwe zastosowanie instytucji magazynu konsygnacyjnego w ramach transakcji krajowych. Istotą wprowadzonego uproszczenia jest zawarcie transakcji pomiędzy podmiotami z różnych państw członkowskich. Instytucja ta ma za zadanie uprościć transakcje wewnątrzwspólnotowe. Wprowadzenie tego uproszczenia dla transakcji krajowych nie miałoby sensu ${ }^{69}$.

\section{Podsumowanie I WNIOSKI}

Należy zgodzić się z przedstawianymi poglądami i ocenić pozytywnie fakt wprowadzenia instytucji magazynu konsygnacyjnego. Przepisy polskiej ustawy o podatku od towarów i usług ograniczają liczbę podatników mogących skorzystać z uproszczeń obowiązujących przy prowadzeniu magazynu konsygnacyjnego. Dzięki wprowadzonym przepisom została zwiększona atrakcyjność polskiej gospodarki. Podmioty zagraniczne decydując się na lokowanie działalności gospodarczej, biorą pod uwagę możliwość korzystania

${ }^{67}$ K. Różycki, Komentarze praktyczne. Czynności zrównane $z$ wewnątrzwspólnotowym nabyciem towarów (WNT), Vademecum Doradcy Podatkowego.

${ }^{68}$ Pismo z dnia 29 marca 2011 r. Izba Skarbowa w Warszawie, IPPP3/443-1298/10-4/KC, Lex Omega nr 58119.

${ }^{69}$ S. Murawski, Czy skład konsygnacyjny może działać na terenie Polski między polskimi kontrahentami? Vademecum Doradcy Podatkowego, nr 174980. 
z ułatwień, jakie dają magazyny konsygnacyjne. W krajach naszego regionu ww. ułatwienia istnieją w Czechach, na Łotwie, Węgrzech, Słowacji i Litwie.

Wyłączone zostały $\mathrm{z}$ tych uproszczeń centra dystrybucji, które nadal muszą rejestrować się w Polsce dla celów związanych z podatkiem od towarów i usług.

Ustawodawca w planowanych pracach nowelizacyjnych powinien zastanowić się nad wprowadzeniem do polskiej ustawy o podatku od towarów i usług przepisów umożliwiających prowadzenie na terytorium Polski magazynu konsygnacyjnego typu consignment stock. Umożliwiłoby to korzystanie z ww. uproszczeń większej grupie podmiotów.

Nie znajduje uzasadnienia pogląd, zgodnie z którym uproszczenie dla WDT obowiązujące w Polsce dla magazynu konsygnacyjnego położonego w innym kraju Unii Europejskiej dotyczy jedynie magazynu typu call off stock. Uproszczenie to powinno również dotyczyć WDT do magazynu konsygnacyjnego typu consignment stock. Faktem jest, że nie dojdzie w tym przypadku do uszczuplenia podatku od towarów i usług. W sytuacji, gdy polski organ podatkowy uzna, że nie doszło do dostawy towarów do magazynu konsygnacyjnego typu call off stock w jednym $\mathrm{z}$ krajów Unii Europejskiej, może dojść do naruszenia zasady neutralności VAT i zakłócenia rozliczenia tej dostawy, jako transakcji WDT. W przypadku braku rejestracji dostawcy w kraju położenia magazynu i podważania przez polski organ podatkowy faktu, że magazyn, do którego przemieszczono towar z Polski, nie spełnia definicji magazynu konsygnacyjnego typu call off stock, dojdzie do podwójnego opodatkowania tej transakcji. Pierwszy raz - według stawki krajowej, a drugi - jako WNT w kraju położenia magazynu konsygnacyjnego. Należy podkreślić, że trudności te nie wynikają jedynie $\mathrm{z}$ winy polskiego ustawodawcy, ale również z powodu braku regulacji wspólnotowych. Ustawodawca unijny powinien określić ramy prawne dla rozliczeń transakcji z wykorzystaniem magazynu konsygnacyjnego.

Przerzucenie obowiązku rozpoznania wewnątrzwspólnotowego nabycia towarów z podatnika zagranicznego na rzecz ostatecznego odbiorcy towarów zarejestrowanego dla potrzeb VAT w kraju położenia magazynu i związane z tym zniesienie obowiązku rejestracji dostawcy w Polsce dla celów VAT oceniam pozytywnie. Przeniesienie obowiązku rozpoznania podatku z tytułu wewnątrzwspólnotowego nabycia towarów na polski podmiot prowadzący działalność gospodarczą umożliwia polskim organom podatkowym dokładniejszą kontrolę oraz wyeliminowanie nadużyć w przypadku transakcji karuzelowych. 


\section{BIBLIOGRAFIA}

Bartosiewicz A., Kosacka-Łędzewicz D., Wewnątrzwspólnotowa dostawa towarów, Vademecum Doradcy Podatkowego.

Bartosiewicz A., Kubacki R., Komentarz VAT, Warszawa 2010.

Brzeziński B., Podstawy wykładni prawa podatkowego, Ośrodek Doradztwa i Doskonalenia Kadr Sp. z o.o., Gdańsk 2008.

Kosacka-Łędzewicz D., Olszewski B., Transakcje wewnątrzwspólnotowe, eksport, import - 2009, Wrocław 2009.

Krywan T., Czy należy opodatkować brakujace towary w magazynie, „Biuletyn VAT” 2010, z. 2.

Lewandowski K., Fałkowski P., Dyrektywa VAT 2006/112. Komentarz, Warszawa 2012.

Łabno P., Definicja magazynu konsygnacyjnego, „Serwis Monitora Podatkowego” 2011, nr 4, System Informacji Prawnej Legalis.

Martini J., Skorupa P., Wojda M., VAT 2009. Komentarz, Warszawa 2009.

Martini J., Skorupa P., Wojda M., VAT 2010. Komentarz, wyd. 2, Warszawa 2010.

Martini J., Skorupa P., Wojda M., VAT 2014. Komentarz, wyd. 1, Warszawa 2014.

Michalik T., VAT. Komentarz, wyd. 8, Warszawa 2012.

Michalik T., VAT. Komentarz, wyd. 12, Warszawa 2016.

Michalik T., VAT. Komentarz, wyd. 14, Warszawa 2018.

Murawski S., Czy skład konsygnacyjny może działać na terenie Polski między polskimi kontrahentami? Vademecum Doradcy Podatkowego, nr 174980.

Musiał K. (red. nauk.), Bartosiewicz A., Założenie magazynu konsygnacyjnego w Polsce, Vademecum Doradcy Podatkowego.

Platteeuw C., Pestana Da Silva P., Quick Reference to European VAT Compliance, http://books.google.pl/books?id=kZHnXzxzUzsC\&num=11\&hl=pl\&redir_esc =y [dostęp 5.04.2013].

Różycki K., Komentarze praktyczne. Czynności zrównane z wewnątrzwspólnotowym nabyciem towarów (WNT), Vademecum Doradcy Podatkowego.

Sach K., Namysłowski R., Dyrektywa VAT. Komentarz, Warszawa 2008.

Skorupa P., Transakcje podlegające opodatkowaniu, [w:] J. Martini (red.), Dyrektywa VAT 2006/112/WE, Warszawa 2010.

Skorupa P., Wojda M., Funkcjonowanie składów konsygnacyjnych oraz call-off stock w Polsce, „Przegląd Podatkowy” 2009, z. 5 (Czytelnia czasopism on-line).

Styczyński R., Składy konsygnacyjne, Vademecum Doradcy Podatkowego, nr 103734.

Tuszyński Ł., Szymaniak K., Rozliczenia transakcji wewnątrzwspólnotowych przy wykorzystaniu magazynu konsygnacyjnego - problemy praktyczne, „Monitor Podatkowy” 2016, nr 6, System Informacji Prawnej Legalis.

Zubrzycki J., Leksykon VAT 2011, Wrocław 2011.

\section{Call off stock in Poland}

Summary. The article presents the conditions for the call of stock in Poland, discusses the rules and problems related to the call of stock, describes the main mistakes made by the legislator and suggests proposed legislative changes that will facilitate the use of call of stock for a larger group of taxpayers.

Keywords: call of stock, consignment stock. 